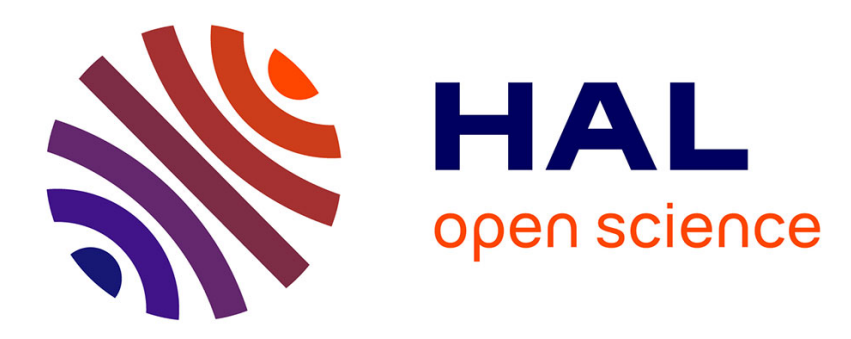

\title{
Of an Enlightenment-Conservative Tone Recently Adopted in Philosophy
}

Serge Trottein

\section{To cite this version:}

Serge Trottein. Of an Enlightenment-Conservative Tone Recently Adopted in Philosophy. 2020. halshs-03098060

\section{HAL Id: halshs-03098060 \\ https://shs.hal.science/halshs-03098060}

Preprint submitted on 5 Jan 2021

HAL is a multi-disciplinary open access archive for the deposit and dissemination of scientific research documents, whether they are published or not. The documents may come from teaching and research institutions in France or abroad, or from public or private research centers.
L'archive ouverte pluridisciplinaire HAL, est destinée au dépôt et à la diffusion de documents scientifiques de niveau recherche, publiés ou non, émanant des établissements d'enseignement et de recherche français ou étrangers, des laboratoires publics ou privés. 


\section{Of an Enlightenment-Conservative Tone Recently Adopted in Philosophy}

\section{Directions}

You must change your life, Peter Sloterdijk writes. ${ }^{1}$ What does this mean? Is he serious? And who in fact utters these words? Who is here talking to whom? Is he really talking to someone? Is this a command, an order, an imperative, or just a reminder, an observation, a simple remark, a mere acknowledgment or report? Sloterdijk plays here the role not only of the philosopher, but also the writer, the playwright, or the director: to understand what he writes also means to understand his direction(s), in every sense of the word - the orders he gives, the staging he creates, and the path he takes. Where Sloterdijk is heading, in which direction, is what we must discover if we are to make sense of what we are reading, of the performance presented to us.

To signal directions and to explain what is at stake in a book is normally the purpose of an introduction, which You Must Change Your Life does not lack: 105 pages in the English edition, that is, fifteen pages called Introduction, followed by The Planet of the Practising, a series of five chapters offering mostly literary examples (Rilke, Nietzsche, Unthan, Kafka, and Cioran), and ending with two more examples (Coubertin and Hubbard) in a so-called Transition (Übergang, and the whole book is after all about übergehen, going beyond), a trans-ition whose title repeats the first

\footnotetext{
1 This essay is based on a reading of two books by Peter Sloterdijk: You must change your life (Translated by Wieland Hoban. Cambridge, UK: Polity Press, 2013) and its extension The Art of Philosophy. Wisdom as a Practice (Translated by Karen Margolis. New York: Columbia University Press, 2012). It was first presented at the International Philosophical Seminar on July 3, 2017 in Castelrotto, Italy.
} 
thesis of the Introduction: Religions Do Not Exist. It is as if You Must Change Your Life started with another book, on a slightly different subject - religions and their existence -, containing nevertheless a whole chapter explaining its title: chapter 1 , about Rilke's poem, which is not yet chapter 1, since the work itself has not yet begun. In fact the book contains so many hors d'œuvres or parerga, that one wonders whether the reader will ever reach its core, if there is one, or head in the proper direction, if there is one, for such an exercise. For the first part itself begins with a programme (Program), the second one with a backdrop (Prospekt in German, perspective in the French edition ${ }^{2}$ ), the third one with a prospect (Perspektive), the whole book ending not with a single conclusion (referring to who knows which introduction?), but with a double one: a retrospective (Rückblick), followed by an outlook (Ausblick, perspective again in French), thus with all kinds of ways of looking into, through, back or forward to something that may well remain to be defined, or even to be found. You must change your life, but how, in which way? Anticipating what future? Or looking back, retrospectively, toward what command? Given this multiplication of perspectives, it is not difficult to become quickly disoriented and to lose what at first seemed to be the guiding thread of the analysis.

More intriguing still are the first theses encountered by the reader: not only that this book is about technics, anthropotechnics, but also about a turn (Wende), and even a return, a revenant, a specter, therefore also a manifesto, an explicitation via a translation: these are all "key terms" that contain "the present book in nuce", as Sloterdijk writes, mentioning only the word ${ }^{3}$ 'explicit'. Explicit, he continues, refers to a rotation, a maneuver, an enterprise, that of rendering explicit the implicit, which Sloterdijk defines as "Enlightenment-conservative".

The translation suggested here of the religious, spiritual and ethical facts into the language and perspective [Optik] of the general theory of practicing [Übungstheorie]defines itself [versteht sich] as an Enlightenment- conservative enterprise [ein aufklärungskonservatives

\footnotetext{
${ }^{2}$ The French edition is: Peter Sloterdijk. Tu dois changer ta vie : de l'anthropotechnique. Trans. Olivier Mannoni. Paris: Libella-Maren Sell, 2011. Hereafter referenced as FE.

${ }^{3}$ In the English translation word appears as world: cf. Sloterdijk, You must, p. 6 (FE 18).
} 
Unternehmen ${ }^{4}$ - a conservatory one [ein konservatorisches], in fact, in the matter itself. It rests on a twofold interest in preservation: firstly, it declares its allegiance to the continuum of cumulative knowledge that we call Enlightenment, 5 and which, despite all rumors of having entered a new 'post-secular' state, we in the present continue as a context of learning [of modern times - moderner Zeiten] meanwhile spanning four centuries; and secondly, it takes up the threads, some of them millennia old, that tie us to early manifestations of human knowledge about practice and animation - assuming that we are prepared to follow on from them [relate to them - an ihnen anzuknüpfen] in an explicit fashion.

With this, we have introduced the key term for everything that will be read in the following: the world [sic] 'explicit', applied to the objects in question, contains the present book in nuce. The aforementioned rotation of the intellectual-historical stage [Drehung der geistesgeschichtlichen Bühne] means nothing other than a logical manoeuvre to render explicit circumstances that, in the masses of tradition, are present in 'implicit' - that is, inward-folded and compressed - forms. If Enlightenment in a technical sense is the programmatic word for progress in the awareness of explicitness, one can say without fear of grand formulas that rendering the implicit explicit is the cognitive form of fate. 6

How an enterprise can be Enlightenment-conservative is what I have tried to understand, and what I would like to render a little more explicit in this essay.

\section{To the inconceivable practitioners of theory}

You must change your life, Sloterdijk writes. Whom does he address? What audience? Are we, as philosophers, part of this audience? Apparently we are, since a second book, The Art of Philosophy. Wisdom as a Practice, is dedicated to this particular subject, philosophers and other practitioners of theory, a book explicitly presented as an extension or application of the first one. Unfortunately the meaning of its title is not much clearer; like the other title, it needs at least to be rendered explicit if we want to understand Sloterdijk's project. Many of these reflections, in a way, will have no other purpose than to develop what is implied and at stake in these two somewhat misleading titles.

Whereas the first title is as enigmatic as it is provocative, the second one hides in its banality the intriguing character of the original: The Art of Philosophy. Wisdom as

\footnotetext{
${ }^{4}$ Not une entreprise de conservation éclairée, as in FE 18.

${ }^{5}$ Cf. FE 18: l'éducation, which unfortunately erases all direct reference to Aufklärung.

6 Sloterdijk, You must, p. 6 (German edition: Peter Sloterdijk. Du mußt dein Leben ändern: über Anthropotechnik. Frankfurt am Main: Suhrkamp, 2009, p. 17. Hereafter referenced as GE).
} 
a Practice is supposed to be the English translation of Scheintod im Denken - Von Philosophie und Wissenschaft als Übung. In the guise of a justification, an introductory "translator's note" provides a few hints, referring vaguely to Kafka as well as "the present debate on the conditions of scholarship", and summarizing the author's argument with an analogy between the practice of science and athletic training. No explanation is given for why Scheintod (apparent death, simulated animation) has been replaced by art, or thinking and science by wisdom. At least Sloterdijk himself is a little more explicit in his Introduction (Theory as a Form of the Life of Practice), written in order to reassure his reader, as he explains in a rather tongue-in-cheek mode: knowing in advance what to expect relieves unnecessary tension (could it be a vertical tension?) and allows serenity (Gelassenheit, maybe?), and dividing one's ideas in four instead of three, seven, or ten sections shows one addresses philosophers rather than theologians, since "the classical philosophical quaternity [...] is based on the assumption that to tell the truth one must be able to count up to four", 7 but apparently not much higher if one does not want to fall back into theology, if I may add.

What should we then expect that would allow us to keep our serenity? First a general talk about philosophy or academic science, represented by two "founding figures", Husserl and Socrates, and secondly, a propaedeutic exploration of "the conditions of the possibility of theoretical behavior" 8 . But these two sections may well be in fact irrelevant or off topic, since only the third (and maybe fourth) sections "go to the heart of today's topic", namely "the formation or self-generation of the disinterested person" ${ }^{\prime \prime}$, finally assassinated under bizarre circumstances. The whole inquiry certainly seems to end as a detective story, but before we jump to the conclusion, Sloterdijk warns us that "one other preliminary remark seems

\footnotetext{
7 Sloterdijk, The Art of Philosophy, p. 2.

8 Sloterdijk, The Art of Philosophy, p. 2.

${ }^{9}$ Sloterdijk, The Art of Philosophy, p. 2.
} 
necessary", a "comment in advance"10, the key in fact to its understanding: we need to be "serious about the term "practice" in all its implications (including as exercise or training)" 11 . Let us be serious then, all the more serious since this remark introduces and establishes the link between two works, Suspended Animation in Thought and You Must Change Your Life. To be serious about practice means to keep in mind what Sloterdijk is aiming at, which he finally sums up here in a few words: "to restore the high status of practice"12.

Practice, he explains, "has been neglected by theoretical modernism, if not wantonly pushed aside and scorned "13, hence its low status for modernity. Yet the situation of practice described by Sloterdijk is much worse than that of a low status: from at least the Middle Ages onward, practice has not only been neglected, it has become invisible, and even inconceivable:

In You Must Change Your Life! I show in some detail how the traditional approach to classifying human action, that is, the familiar distinction between the vita activa and vita contemplativa that initially related only to monks, was linked with the effect of making the dimension of practice as such invisible, if not actually inconceivable. As soon as we accept the ingrained difference between "active" and "contemplative" as if it were an exclusive and total alternative, we lose sight of a substantial complex of human behavior that is neither merely active nor merely contemplative. I call this the life of practice. ${ }^{14}$

Practice then is a kind of in-between, a "mixed domain", which in spite of its medieval and modern invisibility has nevertheless a name, of older origin, like "classical askesis", inevitably mentioned by Sloterdijk in that same context of invisibility. Its definitions continuously shift: practice is exercise, then training, then constitution, virtue, virtuosity, competence, excellence or fitness, ultimately identified to the askesis of Greek or Christian athletes. "The moment we force exercising into distinguishing between theory and practice or the active and

\footnotetext{
10 Sloterdijk, The Art of Philosophy, p. 3.

11 Sloterdijk, The Art of Philosophy, p. 5.

12 Sloterdijk, The Art of Philosophy, p. 6.

13 Sloterdijk, The Art of Philosophy, p. 5-6.

${ }^{14}$ Sloterdijk, The Art of Philosophy, p. 6.
} 
contemplative life - Sloterdijk insists -, we lose sight of its intrinsic value. [...] This structuring of the practical field [...] makes the dimension of the practicing life invisible."15

To force practice or exercising to find its place between theory and... itself would indeed be a tour de force if practice did not also refer to Greek praxis, hence revealing the essential ambiguity of what is here the key term. By pulling practice toward asceticism, Sloterdijk strives to present himself as a Nietzschean philosopher, as is obvious in the very next passage, as in many other throughout his writings:

My book tries to give an impression of the extent, weight, and variety of forms of the life of practice. I quote Nietzsche's evocative remark that, seen from the universe, the planet earth of the metaphysical age must appear almost like the "ascetic star." On this star, the struggle of the discontented nation of the ascetic priests against their inner nature is "one of the most widespread and enduring facts there are." [Here a note, note 2, gives the reference to Nietzsche's Genealogy of Morals] The time has come to cast off life-stultifying asceticism and acquire once again the positive arts of affirmation that have been obsolete for too long. ${ }^{16}$

The danger with an author as prolific as Sloterdijk is to give in to precipitation. For what exactly is he doing here? He is describing one large book from the surface of a smaller one, which appears as one of its satellites. And he starts with two remarks by Nietzsche, which offer us a perspective and a fact. To have the right perspective on life or on the human condition, we need to zoom out, as it were, to see our planet from very far away, from a global point of view, which is going to be Sloterdijk's starting point. Hence the title of the first part of You Must Change Your Life: The Planet of the Practising. But this first part of planet Anthropotechnics (the other name of You Must Change Your Life) is not really its first part, nor is it its introduction either: it is somewhere in-between in Sloterdijk's universe, almost invisible in spite of its size, as if it had been forced to find its place between theory (the object of the small satellite) and itself as the first part, which makes it literally inconceivable, like its inhabitants.

\footnotetext{
15 Sloterdijk, The Art of Philosophy, p. 7.

16 Sloterdijk, The Art of Philosophy, p. 7.
} 
However, the Nietzschean perspective adopted however makes this planet appear as the ascetic star, and reveals a fact, "one of the most widespread and enduring facts there are": asceticism. It is so widespread and enduring, in fact, that the book cannot be exhaustive, and can only give an impression of its extent, weight and variety. It is widespread, but invisible, and in order to make it conceivable, Sloterdijk will have to increase its extension to the maximum, thus ultimately departing from Nietzsche.

\section{The metaphysical age and the aristotelian planet}

Another point of departure, that is, of separation from Nietzsche concerns no longer space, but time: from a Nietzschean perspective one could perceive "the planet earth of the metaphysical age", whereas now the time has come to "cast off life-stultifying asceticism and acquire once again [something] that [has] been obsolete for too long": in other terms, we stand at a turning point, where something is going to return from the past and allow us to overcome metaphysics, to go beyond stultifying routine and rules toward a renaissance of life and free play. That something is said here to be "the positive arts of affirmation", which will require further clarification, as will the delimitation of the metaphysical age preceding the revolution to come.

For the moment, note that the metaphysical age begins at least as far back as the Middle Ages, i. e. the epoch of the "distinction between the vita activa and vita contemplativa", which had the effect of making the dimension of practice invisible. Why? Because it privileges the opposition of theoria and praxis, over lower-ranked human activities like technè and poiesis. Now this opposition goes back to an even earlier epoch, that Sloterdijk does not exclude from his domain of investigation. On the contrary he writes that in The Art of Philosophy his "aim is to show why the idea that the thinking person has to be a kind of a dead person on holiday is just inseparable from the ancient European culture of rationality, particularly classical, 
Platonic-inspired philosophy"17. Thus the metaphysical age may well include antiquity, it needs at least to be thought in Platonic terms (and Nietzsche also tended to identify the history of philosophy with the history of platonism). But if it is platonism whose history Sloterdijk here proposes to narrate or rewrite, the concepts he uses are from Aristotelian origin, and if in the imperative You Must Change Your Life each word has its importance, change is here what is at the base of all definitions or redefinitions leading to the rediscovery of practice. For what distinguishes theoria from the rest is that it is concerned by things that do not change, are immortal or eternal or literally super-natural, that belong to the "supralunar" world; nature, physis, is the domain of change, of growth, of generation and corruption, where technè, praxis or poiesis are found. Whether you must change it or not, life is change. Your life is going to, will necessarily change, whether you wish it or not, whether someone tells you to change it or not. In this (Aristotelian) context, both words mean the same thing and You Must is superfluous: the imperative has not yet found its place. Human beings do not have a choice, they live in the sublunar world, that of physis, which means that they cannot keep from living according to nature, whatever activity they need or decide to perform, and whatever art they try to practise. What distinguishes all these arts and activities (technai) is their aim: if their aim is outside themselves, then they are productions, poiesis; if their aim is inside or none other than themselves, they are examples of praxis. Therefore the domain of praxis is that of ethics and politics, of those who act, and the domain of poiesis that of artisans and artists, those who make things. At least that is how the specter of human activities seems to configure itself on the Aristotelian planet, where Sloterdijk appears to have resided before traveling to a farther planet or satellite. From this more distant point of view, distinctions vanish as quickly as the extension of the concepts increases, forcing them to overlap and invade each other's territory. One concept in particular tends to occupy the whole field, that of technics, whose aim is internal as well as external when its object or objective becomes the anthropos, human being, itself:

17 Sloterdijk, The Art of Philosophy, p. 3. 
hence the term anthropotechnics, which is the subject of the first book and of which the second book offers to its readers another detailed example. Seen from beyond the moon, planet earth becomes the ascetic planet inasmuch as its inhabitants seem no longer to have distinctive and varying activities, but only one: practice, la pratique, which encompasses praxis as well as poiesis. By virtue of a highly invasive extension, the ascetic planet has become the planet of the practising, virtue has become virtuosity, even science or theoria can be thought under the category of training. Practising used to be invisible in the platonic tradition, where theoria served as a model; a simple quarter turn rotation or distancing, and everything else becomes invisible in its turn, the end of oppositions meaning also the end of hierarchies. Once all activities are reduced to a single activity, how and using what criteria can one type of practice still be considered superior to others? We have acquired a new way of defining man or the human condition in general, but we have lost all means of ranking, evaluating, or even preferring one way of living above others, we have lost the very condition of possibility of any morals or ethics, and of any politics. Modern aristotelianism or a certain aristotelian modernity, by virtue of its extension, has erased the platonism of tradition.

\section{Turns and returns, or extensions and rotations?}

Extension, and not only the word explicit as indicated in the introduction of You Must Change Your Life, ${ }^{18}$ is in fact one of the key terms of Sloterdijk's enterprise; besides, it is extension that makes explicit what used to be implicit, and thus invisible. Extension is not however a historical process: practice does not invade little by little all sectors of human life over the course of history, from the religious asceticism of the Middle Ages or even more remote epochs, starting not only with Plato, but even earlier with the pre-Socratics, who, sleepless in Ephesus, were already practising the "art of philosophy", to the contemporary culture of

18 Sloterdijk, You must, p. 6. 
competition, sports and coaching. No change has occurred, there will always have been practice and anthropotechnics, just more or less invisible or masked, depending on the adopted perspective or planet from which these phenomena are viewed. This is phenomenology, not a history, or a philosophy of history.

And yet, from the very beginning, from the subtitles and the title, Sloterdijk speaks of anthropotechnics as a "turn", and of life not just as change, but as submitted to an imperative. It is the turn and the you must that we now need to understand if we are to make sense of the theoretical practice in which Sloterdijk engages in these two books.

It would take too long to catalog all the twists and turns of Sloterdijk's text, and even longer to comment each of them, an exercise I leave to careful readers. The turns multiply in so prolific a way that they end up becoming little more than rhetorical expressions. Each time a new theme or author is introduced, its appearance has to take the form of a turn, even if it is later explicitly denied. One example occurs on the very first page, at the beginning of the introduction of You Must Change Your Life, which starts explaining the anthropotechnic turn by invoking not one but two revenants, a true and a false returnee, the specter of religion and the specter of communism:

A spectre is haunting the Western world - the spectre of religion. All over the country we hear that after an extended absence, it has now returned and is among the people of the modern world, and that one would do well to reckon seriously with its renewed presence. Unlike the spectre of communism, which, when its Manifesto appeared in 1848, was not a returnee but a novelty among imminent threats, the present case [der aktuelle Spuk] does full justice to its revenant nature. 19

However, two pages later, we learn that the revenant in question, the true one, may be equally false: the return or the specter of religion is not going to mark history, because it is just a story, a fiction, ein Märchen, une fable, a myth:

Let us recall: Marx and Engels wrote the Communist Manifesto with the intention of replacing the myth of a spectre named communism with their own aggressive statement of true communism. Where the mere fear of ghosts had predominated, there would now be a

${ }^{19}$ Sloterdijk, You must, p. 1. Thus begins the book. 
justified fear of a real enemy of existing conditions. the present book likewise devotes itself to the critique of a myth, replacing it with a positive thesis. Indeed, the return of religion after the 'failure' of the Enlightenment must be confronted with a clearer view of the spiritual facts. I will show that a return to religion is as impossible as a return of religion - for the simple reason that no 'religion' or 'religions' exist, only misunderstood spiritual regimens [...]. The false dichotomy of believers and unbelievers becomes obsolete and is replaced by the distinction between the practicing and the untrained, or those who train differently. 20 (p3)

Just as practice, as we have seen, cannot be opposed to theory, which is simply another kind of practice, the untrained cannot be opposed to the practising for they are only "those who train differently". The opposition, and the return are mere fables. And the following paragraph reaffirms this, while paradoxically but characteristically clinging to the vocabulary of the return:

Something is indeed returning today - but the conventional wisdom that this is religion making its reappearance is insufficient to satisfy critical inquiries. Nor is it the return of a factor that had vanished, but rather a shift of emphasis in a continuum that was never interrupted. The genuinely recurring element that would merit our full intellectual attention is more anthropological than 'religious' in its implications - it is, in a nutshell, the recognition of the immunitary constitution of human beings. After centuries of experiments with new forms of life, the realization has dawned [hat sich die Einsicht abgeklärt] that humans, whatever ethnic, economic and political situation might govern their lives, exist not only in 'material conditions', but also in symbolic immune systems and ritual shells. It is their fabric that we shall discuss in the following. ${ }^{21}$

Again these statements do not constitute a philosophy of history, whether old or new, but rather a Darstellung, a new presentation, or at least an explicitation, an éclaircissement, a clarification or a different lighting on things, that is, something having to do with Enlightenment, in every sense of the word.

Going back one last time to the "preliminary remark" concluding the introduction of The Art of Philosophy, we find in the brief summary of You Must Change Your Life given by its author the confirmation of the ahistorical and extensive aspect of Sloterdijk's enterprise: his anthropological or anthropotechnical perspective extends to the past, but not to the point of opening toward a revolutionary, or simply different future. Sloterdijk summarizes his book thus:

In You Must Change Your Life! I began by focusing on the ancient systems of practice related to the emergence of ethics in [...] the first millennium BC. [...] In the modern age in

\footnotetext{
20 Sloterdijk, You must, p. 3.

${ }^{21}$ Sloterdijk, You must, p. 3.
} 
Europe, there was a tendency to group these systems together under the misleading heading of "religions" without considering that "religion" was a Romano-Christian term transposed to these phenomena [...]. For the moment, the only question that concerns us is whether we can broaden our insight into the structures of the explicit and implicit life of practice revealed in ancient ethics to the area of theoretical behavior. If I were not sure of an affirmative answer, I would have to break off my investigation at this point. 22

Both books are then first of all extensions of the field of practice. One last digression (but can it still be considered one when there are so many?) refers to what could have been the subject of yet another book, or satellite of the ascetic planet, this time about art history reconsidered and reformulated "as a history of artistic or virtuoso asceticism”. "We could then see, Sloterdijk writes, every phenomenon on this field more or less from a side view and, alongside the familiar history of art as a history of completed works, we could obtain a history of the training that made it possible to do art and the asceticism that shaped artists." 23

Here again, Sloterdijk does not call for a rewriting of art history, but only proposes a side view, a para-history of art, so to speak, where the work of art has been replaced by the training of the artist. How this proposal can "restore the high status of practice" remains nonetheless problematic when one realizes the surprising result created by the change of perspective:

If we assume, as Belting has plausibly suggested, that the tradition of European pictorial culture began with the icon painting of the Hellenized Christian cult, from the start we encounter a form of image-making practice in which art and asceticism represent a perfect unity. The icon painter works with endless repetition all his life, executing a single basic repertoire of a very few motifs in the belief that he is nothing more than the instrument of a supernatural image-light that pours into the work through his hand, always with the basic assumption that the authentic original picture could project itself into the visual world even without human mediation, although this occurs extremely seldom. A direct outpouring of this kind would be a divine photographic slide [...] Christ was such a slide [...] his image on Veronica's veil was also a slide [...] This process set the stage for the steady expansion of artistic methods, as well as for inflated ideas about the importance of the artist. The selfreferentiality of artistic excellence increased inexorably until the watershed at the beginning of the modern age that led to the decline of consciousness about practice in the visual arts. ${ }^{24}$

\footnotetext{
22 Sloterdijk, The Art of Philosophy, p. 8-9.

23 Sloterdijk, The Art of Philosophy, p. 9.

${ }^{24}$ Sloterdijk, The Art of Philosophy, p. 10.
} 
This is perhaps going a little too far, since in the middle of this experiment and of all these assumptions the in-between that the practising artist is supposed to be ends up disappearing, i.e. moving down from the status of a technician to that of a mere instrument or organon of the (already) divine image which the artist no longer reproduces but only projects. The artist is here considered as little more than a slideprojector - hardly a rehabilitation of his or her status.

To keep anthropotechnics from falling into anthropo-organology, as it were, one should probably be careful not to exaggerate the rotation required for the side or backward view, the per- or retro-spective, to appear. No turn is really effected over the course of history; not unlike Kant's Copernican revolution, the anthropotechnic turn is a strategic move performed by the anthropologist, neither a complete revolution, nor a reversal (by hundred eighty degrees), but a quarter turn: "Now it is a matter of turning the whole stage by ninety degrees until the religious, spiritual and ethical material becomes visible from a revealing new angle." 25 Again, The Art of Philosophy, in its proposed reformulation of art history and of the history of science as histories of artistic and scientific asceticism, explicitly asks this rhetorical question: "What would happen if we rotated the conceptual stage ninety degrees in both cases?"26

\section{Conserving modernity}

Now we perhaps can better understand now the intriguing passage quoted at the beginning of this reading, and in which Sloterdijk defines his enterprise as conservative: instead of making or announcing a revolution, it relies on a displacement, a translation, an extension, a quarter circle rotation from praxis to practice, from Aristotle to Nietzsche and Heidegger, establishing neither a new philosophy of history nor a political program or manifesto for a radical social

\footnotetext{
25 Sloterdijk, The Art of Philosophy, p. 5.

${ }^{26}$ Sloterdijk, The Art of Philosophy, p. 9.
} 
transformation, but a revised human geography of our planet. Sloterdijk's enterprise is conservative in the sense of "Nietzsche's Antiquity Project" as defined in the chapter following that on "Rilke's Experience" - that is the second of its "twofold interest in preservation" 27 (6). But it is on its first interest in preservation that I would like lastly to shed some light, that which defines it as an Enlightenment-conservative enterprise, declaring "its allegiance to the continuum of cumulative knowledge that we call Enlightenment, and which, despite all rumors of having entered a new 'postsecular' state, we in the present continue as a context of learning [of modern times moderner Zeiten] meanwhile spanning four centuries". Enlightenment is obviously here just another name for modernity, which Sloterdijk thinks as a continuum (not a series of turns and returns, as the succession of the following chapters might lead us to believe), a continuum extending from the Renaissance to the present, for at least four centuries, and much longer in fact, as is revealed or clarified later in the Nietzsche chapter. This is a continuing modernity, without post-modernity, a modernity of which Sloterdijk claims to be the guardian and even the curator - in French le conservateur (cf. p. 1). It is, by the way, this same conservateur who, in the last section of the last chapter, will complain about the catastrophe of the plastic arts and conclude with the following alternative:

Like the doping-corrupted sport system, the art system is at a crossroads: either it goes all the way on the path of corruption through imitation of the extra-artistic effect in the world of exhibitions and collections, exposing art once and for all as the playground of the last human [obviously not what Sloterdijk calls for], or it remembers the necessity of bringing creative imagination back to the workshops and re-addressing the question of how one should distinguish between what is worthy and what is unworthy of repetition. ${ }^{28}$ (435)

Such is the note on which the book itself closes, that is, before the final Rückand Ausblicke, retrospective and outlook, forming, so to speak, its horizon. Beyond the undeniable condemnation of contemporary art in Nietzschean, but also very traditional, conservative or even reactionary terms (the playground of the last human, art which no longer is art but imitation of the extra-artistic scene, where the

\footnotetext{
27 Sloterdijk, You must, p. 6.

${ }^{28}$ Sloterdijk, You must, p. 435.
} 
virtuoso artist has disappeared, selfishness, absence of imagination, etc.), the book ends with a hope presented as a necessity or a must: in order to avoid the end of art, to prevent art from falling irremediably into corruption, we must go back to the workshops, to repetition, to exercise, to practice. But the necessity of this problematic final return (or shall we say: conservation attempt) cannot hide the question - which seems to have been postponed until this last moment - of which repetition, which practice. It has even become a doubly moral question, in its form (how one should distinguish), as well as in its content (what is worthy and unworthy). The whole problem has now become how to articulate this hidden question, which allows such definitive judgments about art, with the general ascetology and theory of practice that Sloterdijk develops throughout his book.

Although it concerns art, this question is not a strictly aesthetic question; nor is it strictly ethical, at least not in the sense of an ethics as deeply rooted in ontology as Sloterdijk's, "an ethics that does not have values, norms and imperatives at its centre, but rather elementary orientations in the 'field' of existence" (like Heidegger's moods or Stimmungen, he adds"29), and which he also names "First Science" or "First Theory", with capitals in the English and French translations ${ }^{30 .}$ This first theory however contains already, as ethics, the problem it is supposed to solve, namely that of hierarchy and predominance of the worthy over the unworthy, of one opposite over the other one, or in still other terms, the problem of the articulation of theory and praxis. It suffices to read the very awkward deduction of the imperative from Heraclitus's fragment on ethos in chapter 3, Sleepless in Ephesus: what Heraclitus says about ethos presupposes the predominance of thought over non-thought, i.e. of sophronein, diversely translated as Verständig-Sein, good sense, or être-sage, being-wise; therefore his ethics must contain the thesis 'sophronein exists', es gibt sophronein, which, in its turn, must contain more than its "propositional content"

\footnotetext{
${ }^{29}$ Sloterdijk, You must, p. 161.

${ }^{30}$ Sloterdijk, You must, p. 164.
} 
(adding each time in your mind all the necessary quotation marks). Hence the conclusion: "It is an authoritative, spurring and tonic statement that confronts its addressees with the challenge: 'Give precedence to sophronein!' The oldest version of the metanoetic imperative already demands that humans distinguish between the upper and lower within themselves." 31 And if that was not clear enough, Sloterdijk explicitly adds in the next sentence that "the primal ethical directive 'You must change your life!" becomes acute in the pre-Socratic word sophronein - and with a manifestly practice-theoretical tendency"32.

With this fragment we are surprisingly discovering a second torso, the torso of a text this time, as little archaic as the first one and from about the same years, between the sixth and the fifth century, a textual torso which may not see the philosopher as the other saw the poet, but certainly makes a voice heard. We still do not know exactly who is speaking to whom, but we distinctly hear the same imperative, the same sentence, twenty-five centuries later, even though transmitted through Rilke, then Sloterdijk. The experiences of the poet and of the philosopher are similar, the directive they both hear is identical: ontology must contain ethics, and ethics must contain a moral imperative. The problem lies in the meaning of this must: a probability or a necessity, and if a necessity, a merely physical one or rather a moral obligation? How does one go from the horizontality or immanence of life and practice to the verticality and transcendence of the moral imperative? You must change your life! is not the answer to this problem, just its implicit formulation: life is change, then why add to them this dimension of moral necessity? And why is it so necessary to show that it has always been there since the beginning?

\footnotetext{
31 Sloterdijk, You must, p. 164.

32 Sloterdijk, You must, p. 164-165.
} 


\section{Specters of Kant}

After all, change your life! is already written in the imperative. Therefore you must seems to be no more than a superfluous addition, a repetition. Yet, inasmuch as it makes the implicit explicit, it is essential to Sloterdijk's Aufklärung project. We know that he defines his enterprise as a konservatorisches Unternehmen, the task of a curator attached to the preservation of a continuum of knowledge, a context of learning called the Enlightenment. What a close reader soon learns is that such an Aufklärung appears in a mostly Kantian light. Along with Heidegger and Nietzsche, Kantian specters also haunt Sloterdijk's discourse, and they confer to the title voice a specific tone, that echoes other tones recently adopted in philosophy.

References to Kant's vocabulary are not difficult to find, from the critique to the three or four questions leading to anthropology, to the imperative. After his first Critique of Cynical Reason, Sloterdijk gives here his Critique of Immunitary Reason ${ }^{33}$. In the very last chapter of his book, he raises three questions, whose syntax cannot fail to remind us of the three questions mentioned by Kant at the end of the Critique of Pure Reason, in the second section of the Canon of Pure Reason:

All interest of my reason (the speculative as well as the practical) is united in the following three questions:

1. What can I know?

2. What should I do?

3. What may I hope?

The first question is merely speculative. [...]

The second question is merely practical. [...]

The third question, namely, "If I do what I should, what may I then hope?" is simultaneously practical and theoretical [...].34

${ }^{33} \mathrm{Cf}$. Sloterdijk, You must, p. 451, even though the imperative has ultimately become a mere directive: "protectionism of the whole becomes the directive of immunity reason. [...] General Immunology is the legitimate successor of metaphysics and the real theory of 'religions'."

${ }^{34}$ Immanuel Kant, Critique of Pure Reason, ed. \& trans. by Paul Guyer \& Allen W. Wood, Cambridge University Press, 1998, p. 677 (A805/B833). 
In his lectures on logic, speaking then of the "field of philosophy in its cosmopolitan meaning", Kant adds a fourth question, to which the first three relate: what is man? and he indicates where to find their answers, namely in metaphysics, ethics, religion, and anthropology. Sloterdijk seems here to adopt the cosmopolitan perspective, that is the one that puts the emphasis on anthropology, and, as we know, he privileges the third question: if I act as I ought to do, if I change my life as I should, what may I hope? - a question "at once practical and theoretical" in a much more intricate way, as we have seen with the extension of practice, than what Kant was referring to; therefore we also know that its answer cannot be strictly religion, but anthropotechnics.

One should moreover mention the existence of another link between Sloterdijk's general theory of practice and the Kantian enterprise that he is trying to conserve, of which he claims to be the curator: the method or the scheme of extension that is so pervasive in Sloterdijk's book has a certain analogy, if not more, with universalization in the construction of the categorical imperative. To sum up very briefly and loosely what Kant explains with great precision in the Foundations of the Metaphysics of Morals, the reason why morality has to take the form of a categorical imperative is that it cannot be dependent on exterior motives, however high or noble they may be. If it were dependent on something else (the pursuit of the common good, the fear of God, the need to become a better person, etc.), it would not be categorical, but hypothetical. Therefore the moral imperative has no content, and is pure and absolute in that sense, absolutely detached from any conditions or determinations which would make our actions "pathological", to use another Kantian term from this context. As an absolute imperative, if it is one, You Must Change Your Life can have no other content than itself. How then do I know what I should do?

To answer this question, one needs to find, to use Sloterdijk's terms, "a sensible motif [a reasonable means] with whose aid the gulf between the 
sublime imperative and the practical exercise can be bridged"35. This bridge, for Sloterdijk, is General Immunology. In Kant's Critique of Practical Reason, and more specifically in its Typic, it is the universality of law that serves as a schema, or a mediated representation in a kind of schematism analogous to that of the Critique of Pure Reason, except that the imagination of the first Critique is here replaced by the understanding, since there can be no sensible motives for moral action. Let us remember that the categorical imperative does not tell us what to do; its first formulation is: "Act as if the maxims of your action were to become through your will a universal law of nature", and only understanding, the dominant faculty in the domain of the knowledge of the laws of nature, can be of help in such a context. If the understanding is unavailable, then only the sublime remains. Understanding is the faculty of the universal, under which the multiplicity of the sensible, in time and space, is subsumed and synthesized in order to form concepts and thus knowledge. By forming the concept of practice through its maximal extension to the whole domain of human activity, Sloterdijk makes use of a procedure which is analogous to the schematism of practical reason. From that perspective, You Must Change Your Life can be reformulated thus: live your changing life as if everything you do, any exercise you practice, could be thought as a universal law of nature or of mankind. This requires thinking or considering things at a level or distance from where all local egotisms and determinations attaching us to our person, family, class, color, gender, province or nation end up vanishing, allowing us to think globally and "a global co-immunity structure" to be born. ${ }^{36}$ On a more basic level, one could say that this implicit schematism, which I have tried to render explicit, is the moment where so-called verticality is born from the horizontality of the theoretical practice of anthropotechnics, where moral perspective articulates itself with the ontological ethics or ethical ontology born in Ephesus, outside of history.

\footnotetext{
35 Sloterdijk, You must, p. 449.

${ }^{36}$ Sloterdijk, You must, p. 451.
} 


\section{A strange and sublime imperative}

You Must Change Your Life, this sentence which Rilke wrote once is repeated over and over by Sloterdijk, each time with a more or less different emphasis, depending on the context where it is heard. And the light is so often Kantian that we tend no longer to distinguish between a grammatical imperative and moral or practical one. It is nevertheless, if you listen to it attentively, a strange imperative, which may explain why Sloterdijk calls it absolute or sublime rather than categorical. To express the imperative other than through a mode, one can use an auxiliary verb, namely sollen, as Kant himself indicates. Rilke however writes, and Sloterdijk repeats without noticing: Du mußt (instead of Du sollst) dein Leben ändern. You Must Change Your Life, then, says the voice, instead of You Ought to Change Your Life. Now if you must, it means you do not have the moral obligation to do so, in fact you have no choice and there is no question of will: you will eventually change your life, you simply have to, whether you wish it or not. It is almost like saying: you will die, all humans must die, there is no question about it, it is a fact, even a fact of life, a fact of physis, a natural thing. The verticality of the order seems to have again disappeared.

But not its authority - and Sloterdijk is desperately in search of an authority, of something that will give authority to his discourse. That is the main reason why he chose such a seemingly dogmatic or arrogant title and why he begins with Rilke, that is, with a poem or a work of art. His ontologico-ethical and ascetological discourse requires the aesthetic and the artistic dimensions, for it is paradoxically the aesthetic that frees us from the threat and domination of the ethical. "Beginning with a poetic text seems apposite [günstig - Gunst being one of the fundamental concepts of Kant's aesthetics]", he writes, because "the powerless superiority of the works can affect observers who otherwise take pains to ensure that they have no lord, old or new, above them"37. Even though Sloterdijk almost

${ }^{37}$ Sloterdijk, You must, p. 19. 
constantly uses the Kantian term imperative, the command does not in fact come from reason or Being, but from a stone, a work of art, a poem, which no longer imposes, but exposes itself; hence its sublime effect.

Yet this effect cannot last for ever, it is vanishing, it can already no longer be heard today in art, religion or wisdom. "The only authority that is still in a position to say 'You must change your life!' is the global crisis [...]. Its authority is real because it is based on something unimaginable of which it is the harbinger: the global catastrophe [...] the Great Catastrophe [with capital initials...] the goddess of the century [...] the monstrous [...] much like the God of monotheism [...]." 38 The Enlightenment-conservative tone adopted at the beginning has now taken, at the end of the book, such an apocalyptic turn that a detailed analysis of its stakes and implications would require at least another study; for it would inevitably have to tale into account Derrida's analysis of the apocalyptic tone, which was itself already a deconstructive reading of Kant's opuscule Of an Overlordly Tone Recently Adopted in Philosophy, while being at the same time a defense and illustration of deconstruction as a continuation of Aufklärung. ${ }^{39}$

Kant's three questions about knowledge, morals and religion become in Sloterdijk three questions about saying, hearing and doing what the imperative prescribes: Who may say it? Who can hear it? and Who will do it? It prescribes everything and nothing, is everywhere and nowhere at the same time, is pronounced by or (rather) from a stone, but heard by indifferent spectators trying to deconstruct its warnings. It demands that "[at] every moment, I am to estimate the effects of my actions on the ecology of the global society. [...] I am meant to stand my ground as a citizen of the world, even if I barely know my neighbours and neglect

\footnotetext{
38 Sloterdijk, You must, p. 444.

${ }^{39}$ Cf. Immanuel Kant, Von einem neuerdings erhobenen vornehmen Ton in der Philosophie (1796); Jacques Derrida, "Of an Apocalyptic Tone Recently Adopted in Philosophy", Oxford Literary Review, Volume 6 Issue 2, p. 3-37; and Serge Trottein, "D'un autre ton adopté naguère en déconstruction", in Perspectives on Contemporary Literature, vol. 12 (Self and Other), Lexington, Kentucky: University Press of Kentucky, 1986, p. 57-64.
} 
my friends." 40 No wonder that such an imperative, if there is one, is not quite ready to be put into practice. But once it is, we will have preserved in one fell swoop the Enlightenment, the Renaissance, and Antiquity. 